Article

\title{
Black Lives Matter! Nigerian Lives Matter!: Language and Why Black Performance Matters
}

\begin{abstract}
Abimbola A. Adelakun
African and African Diaspora Studies, University of Texas at Austin, 210 W. 24th Street, Mailcode E3400, Austin, TX 78712, USA; adelakun@austin.utexas.edu

Received: 23 March 2019; Accepted: 9 April 2019; Published: 14 April 2019

Abstract: This essay explores performance as a language by looking at its appropriation by other cultures, and the associated history of the crafted phrases that are borrowed along. I start by noting that to create awareness of the massacres that have recently occurred in some parts of Nigeria, commentators, both in and out of the country, and activist-cum-protesters created the term "Nigerian Lives Matter." They appropriated from "Black Lives Matter," the American-originated advocacy movement that campaigns against violence and brutality against black people. I show that these forms of lexical interchange are possible because of non-Americans' familiarity with America's racial history, and black performance liberation expressivity, which they have been acculturated into as a result of their long exposure to American culture. Beyond phrases however, I argue that black performance itself is a language that has a global resonance among minorities. To illustrate this further, I do a close reading of This is Nigeria, a recent music video released by Nigerian lawyer turned artist, Folarin Falana (Falz), alongside a version of the original production, This is America, also recently released by Donald Glover (Childish Gambino). Both songs continue in the older tradition of African and African American transatlantic political relations through music, the shared understanding of the similarities of anti-black oppression, and the formation of aesthetics that mediate the advocacy of black liberation. The songs are also a pointer to how black advocacy might continue to unfold in contemporary era.
\end{abstract}

Keywords: performance; language; Black Lives Matter; Nigerian Lives Matter; black liberation

To create awareness for the massacres that have recently occurred in some parts of Nigeria, commentators, activists, and protesters, both in and outside of the country, have created the term "Nigerian Lives Matter."1 They appropriated the phrase from "Black Lives Matter," an advocacy movement that originated in the USA and which campaigns against violence and brutality against Black people. Black Lives Matter (henceforth, BLM) began in the United States as a drive against anti-black violence, another wave of pushback that was energized in the wake of the Trayvon Martin killing. ${ }^{2}$ More than sloganeering, BLM functions as a dense political statement that encodes the urgency of acknowledging Black humanity, the decades of history of advocating for it, and the yet-to-be-resolved issues that continue to give the declaration of Black humanity currency. While the primary focus of the BLM movement has been on the afterlife of slavery—systemic racism, racialized criminal justice system, racial violence, and particularly, police brutality ${ }^{3}$ - the campaign has had a resonance with ethnic and racial minority groups outside the US. The intensity of the statement, BLM, reverberates across locales outside the US. From the United Kingdom to Canada, Australia, Ghana, Israel, Nigeria (and

\footnotetext{
(Jegede 2018; Wilson). See also the social media pages dedicated to the Nigerian Lives Matter projects. (Clare 2016; Davary 2007; Edwards 2016).

(Hartman 2007).
} 
its diasporas), BLM is an anthem of resistance that has been variously diffused with local angst and which has spawned different versions that articulate different issues to different audiences. ${ }^{4}$ This essay is an argument that Black performance in its ramifications is a language, and a universal one at that. This factor makes it open to mimesis by other cultural agents who use it to transcend the babel of advocacy efforts into a singular tongue. When Black performance is appropriated for social activism, the associated history of the crafted phrases and aesthetic actions are borrowed as well. The dialogical and convivial artistic exchange that occurs spawn social formations across disparate Black cultures.

Not merely titular, Nigerian Lives Matter is wrought from a cultural stencil that samples the Black American protest semaphore, compresses the political economy in the universal nature of USA socio-political and socio-cultural performances, and re-presents it within the frame of Nigerian politics. Nigerian Lives Matter also illustrates how the globally circulated aesthetics of Black American performances surpasses ideo-spatial bounds, animates resistance practices of other cultures, and impregnates them with social and semantic resources to mobilize against oppressions and injustices in their local communities. Black performance is ontologically political, and it authorizes the codes that provoke the articulation of deeply sedimented attitudes and world views, particularly among subaltern populations. These codes construct the social world and make both situations and the framed responses to them mutually comprehensible.

My analysis will focus on This is Nigeria, a recent music video released by Nigerian lawyer turned artist, Folarin Falana (Falz), and the original production, This is America, also recently released by Donald Glover (Childish Gambino) and to critical acclaim. ${ }^{5}$ I focus on the phenomenality of the hip-hop culture and contemporary music scene that foregrounded-and continues to sponsor-some of these socio-political critiques and aestheticized resistance engagements in non-USA cultures. ${ }^{6}$ The songs by Childish Gambino and Falz continue in the older tradition of African and African American transatlantic political relations through music, the shared understanding of the similarities of anti-Black oppression, and the formation of aesthetics that mediate the advocacy for Black liberation. This symbiotic artistic exchange and political negotiations of Black identity was particularly visible in the 1960s representations between Black artists and activists, such as John Coltrane and Babatunde Olatunji, Miriam Makeba (particularly in the light of her marriage to the proponent of the Black Power Movement, Stokely Carmichael), and Maya Angelou and her sojourn through Africa. ${ }^{7}$ Also, the role of Afrobeat creator, Fela Anikulapo-Kuti, is quite significant in this regard. His musical career and politics was a key bridge through which the Black Power Movement and other racial, social movements not only traveled to Africa, but also were translated into a local social dialect that captured the intricacies of politics in postcolonial Africa. ${ }^{8}$ Fela made the Black Power Movement popular within Africa because his music expanded the historical consciousness of the average African to the global Black struggle. By connecting the dots of the ongoing intellectual exchange of the Pan Africanist movements of the era in his songs, and by using the iconic Black Power symbol of the raised fist, he created a legacy of resistance that was both racial and national in outlook. ${ }^{9}$

4 See articles: "Black Lives Matter Needed in UK" by BBC and YouTube video on protest against Police brutality in Israel."Black Lives Matter Needed in UK." 5 August 2016. British Broadcasting Corporation. https://www.bbc.com/news/uk-36982748 (accessed on 17 September 2018).“Protest Against Racist Police Brutality in Israel.” YouTube.com. 8 January 2015. https://www.youtube.com/watch?v=eRfW9PpRawY\#t=15 (accessed on 17 September 2018).

5 This is America was released on May 5 and This is Nigeria followed on 25 May 2018.

6 As (Shonekan 2018) pointed out in her analysis of the connection of music and Black Lives Matter protests, every generation and its black liberation struggles have been backgrounded with the sound of the music of its times. For a related analysis, also see (Maultsby 1983).

7 (Feldstein 2012; Fleming 2016; Sizemore-Barber 2012).

8 (Botchway 2014). Also see: (Olaniyan 2004).

9 In 2012, Nigerians, along with counterparts in other countries, began their own version of mass protest in the fashion of the Arab Spring (2010) and the "Occupy" movement that had taken off in the USA (2011). The protests began as a pushback against the planned removal of the fuel subsidy by the government of Dr. Goodluck Jonathan, and the consequent multiplier effects it. would have on consumer goods. What is interesting about the aesthetics of this protest is that the logo that was created was the raised Black Power fist, popularized by Fela whose music also was the background sound of the protests. 
In a similar vein, both This is Nigeria and This is America are performance narratives where one copies the other. Mimesis as a strategic selection of human performances is a theatrical art that, according to Elin Diamond, could lead to the cognition of "ethical universals." 10 In this context, mimesis provides a frame for two related elements: (1) juxtapositions of anti-Black circumstances across cultures and (2) popular culture performance as a facilitator of the translatability of one culture's social narratives through the semiotics inscribed by another's artistry. ${ }^{11}$ Translatability galvanizes disparate interest groups across various world cultures that converge along the highways and byways that contemporary performances travel-social media-to share stories due to the grid-like formation of the medium. These diverse cultures potentially understand phenomenal events about each other, not only because performance has a universal purchase for creating meaning, but because these events are also accorded a shorthand language that summarizes the issues at stake within the familiar paradigmatic history of anti-Blackness. By saying "Nigerian Lives Matter," rather than any other locally generated expression, the violence against Nigerian groups not only becomes more amplifiable, but also allows us to shape the ideals that connect Black histories across space and time.

The socio-cultural and socio-political formation that are put together by these resonances of racial dignity across national borders reflects some of the reality of Black internationalism in the contemporary era. First, due to the ubiquity of global communication technology, the language with which we challenge anti-Blackness might be culture and history specific, but it is also spoken with a global accent. Second, this cosmopolitanization of the struggle re-translates local angst and gives it a resonance that is galvanizing because most of its local audience was socialized within a broader global culture. To say Nigerian Lives Matter is to appropriate the conscientization embedded in the sonic gravity that BLM carries, and understand oneself as a Black subject connected to historical struggles elsewhere. Third, despite the immense potentials of framing issues within a global explanatory paradigm, the contours of the contemporary wave of Black social movements is only still emerging. For now, the proponents of racial dignity across national borders have yet to consciously connect as comrade-advocates to produce a grand narrative of global Black liberation similar to previous Black self-determination groups such as the Black Consciousness Movements, Independence and African Nationalism Movements, Pan-Africanism Movement, and Negritude Movements. There is also no grand hero in the mold of Kwame Nkrumah, George Padmore, Malcolm X, Marcus Garvey, Steve Biko, and Martin Luther King Jr. In place of a global manifesto that has express political goals, and employs social, aesthetic, and economic means to achieve them, what we currently have are pockets of resistance that occasionally erupt as a result of a buildup of tensions and resentments in different contexts. This level of the diffusion of the struggle is largely a product of the times. The world is fragmented, the imperatives driving the agenda of Black liberation across space and time vary radically, identities are in flux, and unlike before, global networking can take place without a physical convergence of bodies or even a set of agendas to be ticked as they are achieved.

\section{The Intellectual Context}

The vast body of scholarship that has explored Black internationalism movements across the globe has touched on the transnational transfer of affects, ideology, bodies, and the ways Blacks and people of color have risen to the challenges of the time to assert their human dignity amidst denigrating conditions that range from slavery to colonialism. From C.L.R. James' A History of Pan African Revolt to recent works in the field that are exploring how the shades of identities also impacted Black social

This showed the resilience of the legacy of these movements. For more on \#OccupyNigeria, and especially the role played by the social media in advancing the pushback, see: (Chiluwa 2015; Egbunike and Olorunnisola 2015; Hari 2014; Ibrahim 2013). 10 (Diamond 2003).

11 In Translation and Globalization, Cronin (2013) critically explores how the changes globalization has wrought-modern technology, automation, capitalism, cultural power, institutional forces- have affected language translation. While I rely on his insights to define translation, I do not quite mean it in the literal sense of expressing the text of one language into another. What is being translated here are history and affects, as they are mediated by blackness. 
movements, these studies have mostly been historical, casting lights on the roads that those movements have traveled in the past. ${ }^{12}$ This paper leans on them for critical insights, and will look at history from the lens of the past to speculate on how the politics of Black internationalism might develop from now to the nearest future and what role digital technology might play in the evolution of these movements.

These varied texts include Colored Cosmopolitanism: The Shared Struggle for Freedom in the United States and India, where Nico Slate finds the ideological links and social visions that bind the transnational struggles of "colored peoples" against white supremacy in the different corners of their world. He shows how people abjured particularistic differences, considered their struggles analogous, and built a transnational network to assert the humanity of the Black subject. ${ }^{13}$ From Toussaint to Tupac: The Black International since the Age of Revolution is an equally illuminating compendium of Black histories which internationalize the struggle within the historical contexts of the Enlightenment, the Haitian Revolution and its fallouts, the World Wars, the nationalist and anti-colonial movements in Africa and elsewhere, the Cold War, the Great Migration, and the Civil Rights Movement. The book illustrates the conscious connections of local struggles to global paradigms of Black liberation, which has at its core "the ideal of universal emancipation, unbounded by national, imperial, continental, or oceanic boundaries-or even by racial ones." 14

More recent texts like Keisha Blain's Set the World on Fire: Black Nationalist Women and the Global Struggle for Freedom have highlighted the role played by Black women in the organization of Black liberation movements, and the ideological musts that drove their passion as activists and organizers. ${ }^{15}$ Her works provide a counter-balance to similar narrations that have focused on the roles played by mostly male actors in the global movements. ${ }^{16}$ More specifically, Ingrid Monson's Freedom Sounds: Civil Rights Call Out to Jazz And Africa interrogates how the transnational Black politics of the 1960s intersects with the struggle for civil rights, the Cold War, and the anti-colonialist/nationalist movement; and how these factors were blared out in the trumpeted notes of jazz by artists like Louis Armstrong. ${ }^{17}$ In the spirit of looking back to see ahead, other writers like Krystal Strong have decried the thawing of the Black internationalism that lit the 1960s aglow and called for synchronization of resistance efforts by non-USA Black cultures under the umbrella of the BLM movement. ${ }^{18}$

These aspects of Black transnationalism have been uneven, ideologically inconsistent, and variously impacted by the evolution of world histories. ${ }^{19}$ While there are questions of what such a global liberation movement can - or needs to-achieve even if the past golden eras can be reignited, one also runs against the question of the tools that have the potential to provide a global language that can synthesize issues, ideologies, and different anxieties to which everyone can relate. As Michael West et al. noted, organizational efforts to launch similar waves of political revolution that once captured the world and changed historical formations significantly have not quite taken off the same way as they did in the past. However, that does not mean there are no more Black formations. The areas where the connections of Black identity have emerged have shifted from the overt politics and the intellectual traditions created to tackle them, to the arena of the hip hop movement and its various offshoots in the areas of film, fashion, and media. ${ }^{20}$ The contemporary music scene is providing the ideology of transnational and transcendental Black liberation that matches the rhythms of the times, and they have managed to spread this consciousness through new media technology.

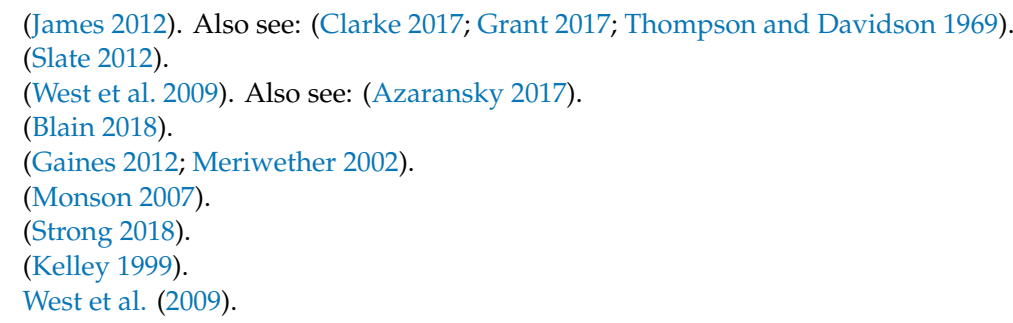




\section{This is America and This is Nigeria!: This is a Critique of Anti-Black Violence}

Since the same repressive conditions that imperil human lives are also the ones that press the human creative impulse into making the art that critiques and resists them, This is America comes across to the viewer as a juxtaposition of violence and entertainment. The song and the choreographed dances feature a combination of artistic traditions that range from African melodies and moves, African American music traditions that include the hip hop culture, and the contemporary traditions of cyber-generated "viral" performances. This is America features a bare-torso Childish Gambino dancing through a warehouse while episodic series of violence and chaos are enacted behind and around him. Childish Gambino is accompanied by a group of dancers in school uniform who perform different dances, including the South African Gwara Gwara. The dances are punctuated with violence, such as Childish Gambino shooting a man sitting on the chair in the back of his head with a handgun, while assuming the iconic pose of the figure caricatured in Jim Crow era performances. Childish Gambino soon graduates to an automatic weapon which he uses on a church choir, a reference to the tragic shooting in a Black church in Charleston, South Carolina, in 2015.

The video is laden with symbolic references to current political events and instances of anti-Black violence in the USA such as fatal shootings and arrests by police at traffic stops, racist history, drug cartels amidst the hysteria about "undocumented" Mexican immigrants, the hyper-capitalist obsession with guns and patriotic pretensions of gun ownership despite the culture of violence it has perpetrated, and overall pessimism about the irresoluble circumstances that surround Black lives within the context of American history. Throughout the video, and amidst the chaos, smoke, flashing hazard lights, and the persecution of Black people, Childish Gambino's exposed body reminds us of the vulnerability of the Black bodies that exist in the mix of the racist circumstances of the USA. On the one hand, This is America pushes us to see a United States where the prevailing ideology of violence treats Black bodies as fungible and subjects them to gratuitous violence. On the other hand, This is America's emphasis on dance also subtly indicts Black America-as a subset of the larger nation-in the violence that imperils Black lives. Childish Gambino shows that the resilience of Black culture, its resoluteness in the face of wanton violence, and the unattenuated cheerful spirit that continues to affirm Black humanity are acts of self-misrepresentation of pain.

The disquieting nature of the pessimism with which Gambino opens and closes the curtains on This is America notwithstanding, many people found the narrative gripping enough for the video to quickly garner mass online viewership. Within 24 hours of its online release, 13 million people had watched the video and as of October 2018, five months after its release, more than 410 million people had viewed it from all over the world. One of the attributes of the internet age is the dizzying speed with which artistic productions like This is America "go viral," and worm their way into global circulation routes where the spectacular nature of the content eventually takes preeminence over the context that produced it. This is America, as it "landed" in different parts of the world, hatched an array of responses that used its content of socio-political critique as a formula to address local situations; the volume of their voices enhanced by the loudness of the bang with which the video hit the internet. The narrative frames of the video were taken apart and reconstructed into parodies, mimicry, memes, Twitter commentary, hashtags, and playful re-interpretations of the intent of the original video. This is America thus became a wellspring of artistic imaginations that sought to formulate the critique of different local situations through a depiction of an essentialized definition of the United States.

Four days before Nigeria's Democracy Day on 29 May, 2018 and shortly after the release of This is America, Falz launched This is Nigeria. ${ }^{21}$ He capitalized on the attention that This is America had generated and quickly used it to launch a blistering critique of the Nigerian situation. The song

21 FalzVevo. "This Is Nigeria." YouTube.com. 25 May 2018. Accessed 15 September 2018. https://www.youtube.com/ watch?v=UW_xEqCWrm0; Donald Glover. "This is America." YouTube.com. 5 May 2018. Accessed 14 September 2018. https://www.youtube.com/watch?v=VYOjWnS4cMY. 
used the original version as a template to formulate critiques about the state of the Nigerian nation, translating a chain of local phenomena with the artistic scaffold constructed by This is America. Falz, son of famous lawyer and human rights activist, Femi Falana, preempts the video with the voice of his father stating that Nigeria operates a "predatory neo-colonialist capitalist system" established on corruption, and which reproduces corruption. Falz himself appears in the video with his torso equally bare, while he makes his way through a warehouse where a series of actions are taking place just as it was in This is America. The video goes on to dramatize the Nigerian catalogue of woes that are not redressed: infrastructure deficit, corruption and the cynical ways it sometimes operates, incompetent leadership, religious and ethnic violence, insecurity, electoral malpractices and violence, miracle preachers, ineffective leadership, sexual assault, opioid epidemic, cultism, and the workings of a neoliberal economy that makes women resort to prostitution. While This is America featured schoolchildren in uniform, This is Nigeria featured school-age girls in hijab doing the popular Shaku Shaku dance. The girls' dance alludes to the terrorist violence that saw to the abduction, forced Islamic conversion, and marriage of 276 girls in Chibok, Borno state in 2014, and yet another incident of 110 girls kidnapped from their boarding school in Dapchi, Yobe state in 2018.

The release of This is Nigeria was timely; it preempted the Nigerian state's annual rituals of reading a litany of Democracy Day speeches and a performance of activities that are supposedly intended to boost the collective sense of nationalism. On these occasions, the president typically engages in one-way communication with the citizenry, to state the (meager) achievements of their administration before they go on to make more promises for the future. Instead, This is Nigeria ambushed the process by combusting the gilded surface of the official narrative to reveal the unflattering reality. This is Nigeria, and its timing also gave Nigerians a space to express their dissent with the things wrong with their country. The video created so much attention among both local and international audiences, especially after it was shared by hip hop star, Sean Combs (Puff Daddy), which only expanded its reach. Days after its release, a group called Muslim Rights Concern (MURIC) demanded the withdrawal of the video because they thought it portrayed Muslims and the ethnic group represented in the video as murderers (part of the real-life situations that created the "Nigerian Lives Matter" movement) in an uncomplimentary manner. They described the video as "thoughtless, insensitive and highly provocative" and threatened to sue the artist if he did not withdraw the video and apologize to Muslims. Given Nigeria's history of eruptions of mindless violence and massacres in Islamic-dominated regions of the country because some vagabond Muslims took offense at the representation of their religion, MURIC's warning was taken seriously. The actual threat, everyone knew, was not to resort to litigation as they warned, but the senseless violence vengeful Muslims could unleash on innocent victims. Eventually, a series of behind the scene manipulations led to the song being banned from being played on radio stations.

\section{Speaking in Blackness: Of Musical Performance and Interconnected Black Politics}

Studies of the rhizomatic nature of the contemporary music scene-the global hip hop culture and its elements-have explored the aesthetics of language and the deterministic politics that inform the choices performers make on how they communicate to arrive at complex, but informed destinations on the aural enterprise that surround music performance communication. Their multi-discursive thesis on the dynamics of language in contemporary music performance culture can be broadly categorized into two mutually overlapping categories: (1) Those that treat language as a linguistic discourse. They primarily explore the inventiveness that occurs in different contexts when the language in which hip hop is expressed-English- interfaces with diverse local ones in other cultural settings. These scholars analyze language in hip hop and popular culture theoretical filters that also gauge how different sets of political and identity concerns, that span different locations, are manifested and resolved (or not). Language is treated as the intense negotiations of identity and subjectivity that occur alongside the domiciliation of Black American lyricism, standardized English language, and their interfaces with local tongues and dialects. 
In works such as Global Pop, Local Language, Global Englishes and Transcultural Flows, The Languages of Global Hip Hop, Language, Localization, and the Real: Hip-Hop and the Global Spread of Authenticity, Global Englishes, Rip Slyme, and Performativity, and Global Linguistic Flows ${ }^{22}$ scholars broadly examine the multivariate dimensions of language in global hip hop culture. They cover the range of cultural complexities that are tickled when music comes to us through our politically processed aural faculties that hears, discerns, and compels the body to respond in its own way. These include the broad and nuanced spectrum of music lyrics, diction, dialects, multilingualism, syntactic formations, interpretations, and other processes that are stimulated through music, and describe a comprehensive set of practices that effectively signposts hip hop as a giant overflowing basket of practices filled up with histories, cultures, and genetic mutations of aesthetic practices that cuts across locales. Following J.L. Austin, we know that language does not merely describe or label situations but is performative as well; it can inscribe and institute practices. ${ }^{23}$ The language of music performance is compelling; they circulate through cultures where they instigate more performances. They also enact networks of social relations within local scenes and set the terms of the institutions' memberships.

Sequel to the politics of language in popular music performance they examined is also comprehensibility, both in the sense of what is known and that which might be unknown, but whose meaning is manufactured to fulfill a defined set of longings. For instance, in Swag' and 'cred': Representing Hip-Hop in the African City, Caroline Mose demonstrates how the transcultural interchange of the hip hop culture is mobilized by Kenyan artists who navigate their urban spaces in an increasingly globalized culture by adopting racialized epithets such as "hood, swag, cred, nigga, and ghetto" to highlight their local experiences. ${ }^{24}$ Their hip hop narratives and descriptive terms start as mimetic by identifying with its double elsewhere until it develops its unique aura and essence. ${ }^{25}$ In capturing their local histories and their performative agencies within Black American terms and expressions, these cultural producers demonstrate a creative insight into an nderstanding of Blackness and the racial/cultural terminologies that are used to label racialization.

In the second category of the scholarship are those that inquire not just about the verbal portion of a hip hop performance, but the contemporary music of Black cultural productions as a commentary with an evocative message that universally speaks to individual local contestations of identity, marginality, and oppression, particularly among the youth demographic. ${ }^{26}$ In this category, Black performances and its hypervisibility of bodies that demand that its humanity be acknowledged inspire other subaltern populations of the world to consciously align with the Black identity and Black American history to confront their situations. Halifu Osumare described the resonances of political awareness and pushback through appropriations of politically charged aesthetic acts across hip hop cultures as "connective marginalities," and it takes on different colorations of oppressions such as race, gender, class, generations, and other forms of peripheral status. ${ }^{27}$ Even when the issues at stake were particularistic Black American intramural discourses, they have resounded through transnational, transcultural, and cybercultural spaces where they acquired nuances of meaning within layered arcs of history and culture. ${ }^{28}$ Whether they are youths in urban spaces in Tanzania, consciously identifying with the aesthetics of the USA's hip hop cultures, or Arab-American hip hop artists constituting their immigrant experience within the racialized ones of African Americans by claiming "Arab" is the new "Black", hip hop has initiated a cultural semantic of awareness, identity, and liberation ethos. ${ }^{29}$

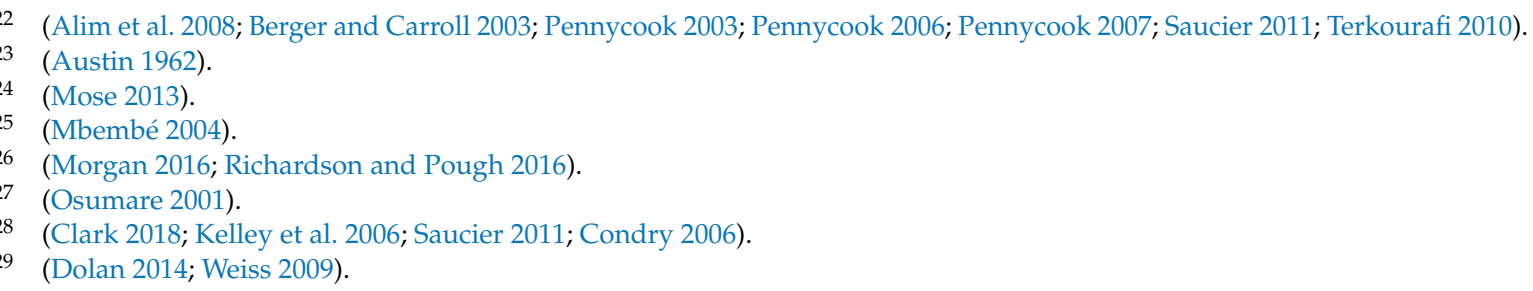


Ela Greenberg, for instance, writes about a Palestinian crew called G-Town who adopted Black American hip hop culture to sensitize others about their local circumstances of occupation. They have lived in refugee camps alongside its social problems of drugs and violence, and thus the racialized urban settings of the American ghettos and the "hood" reverberates with them. They devolved towards rap music as an experience which creates meaning, because they consider the disempowerment caused by their social conditions similar to that of African Americans. Like their Black American counterparts, hip hop divines their condition and also provides them with aesthetics and social rituals to validate their humanity and redefine the conditions of their existence. These Palestinian artists use the late Tupac Shakur and his gangsta image — that is, the "menacing" Black hyper-male—as their emblematic model to shore up their masculinities degraded by the occupation of their land. ${ }^{30}$ Such examples of appropriating Black culture to articulate local struggles thus construe Black identity as a position of resistance, and Black performance as a methodology for resisting oppressive ideologies of whiteness. Dexter Thomas' study of hip hop culture among conservative right-wing factions in Japan presents a somewhat more complicated category where Black culture and performances are admired enough to make "niggas" correspond to "Japs," but otherwise does not constitute the expansive liberalism that Black culture has facilitated elsewhere. While these Japanese conservative groups become "Black" to critique their victimization, they are-in another context—-the oppressors. ${ }^{31}$

This essay teases out another fold over in the imbrication of performance and language using This is America/This is Nigeria as an illustration: one that considers Black performance as a radical praxis that shapes ideological language and a universally apprehensible system of signs whose cross-cultural relatability reflects the glossological transcendence potential of performance traditions. For definition, my conception of "Black performance" alludes to Patrick Johnson's argument that Black performances have always been a central part of liberationist struggles. ${ }^{32}$ Johnson's references primarily index African Americans' staging of culture and history, political aesthetic, spontaneous and disruptive eruptions of the norm, reflexive practice, embodiment, a dialogical engagement with its local American society, but I also note that Black performance and its radical aesthetic are a lexicon that has crisscrossed cultures. By "language," I mean an inscriptive system of racial and visual imagery, embodied acts, and perceptions with the potential of transcultural and trans-temporal comprehensibility rather than a set of syntactic or lexical customs being appropriated, authenticated, and calibrated into local forms.

This idea of performance as a language is boosted by an acculturated understanding of the USA culture and is adaptable according to contextual imperatives. As the various examples of local appropriations of BLM (and recently, This is America/This is Nigeria) show, non-American cultural performances find it easier to borrow the language of Black performance because of their prolonged exposure to American cultures through its pervasive media. The rate of the contact has created in them an instinctual understanding of hierarchies of (racial) identity; a familiarity, along with a somewhat savvy apprehension of the social mechanisms that power social inequalities; and a semiological and hermeneutic competence of the Black American experience enough to constitute those experiences as a paradigm to re-narrate theirs. By "performance," I also mean a mega discursive frame that captures theatricality, embodied engagements, spectacles, and social cultures. I assert that performance in itself is an expressive act of optimism, a stressor of oppressive structures, an assertion of the political conviction that even the conditions of social death and vulnerability can be challenged through the articulation of power of performing bodies. That is, the ability of the body to state the specificity of its situations of "imperiled livelihood, decimated infrastructure, and accelerated precarity through its sheer indexical force." 33

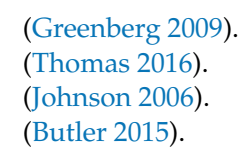


Hip hop scholar, Thomas F. DeFrantz, has explored the notion of the Black dancing body and its ability to index "narratives of transcendence" based on its kinetic virtuosity. The Black body in creative action carries a double desire that is locked into its tenuous history and which is released in dance. He engages in arguments that frame the communicative function of Black performance as a code that is multivalently understandable to different racial audiences based on their level of cultural competence or "literacy"-a terminology that underscores the argument that performance can be read like a material text. Rather than characterize Black performances as a language, DeFrantz renders them as analogous to verbal language and explores the circuit of communication that uses the body's movement, musical instruments, and social history to convey meaning. He says, "Dance movements convey speech-like qualities which contain meaning beyond the formal, aesthetic shapes and sequences of movements ...". DeFrantz also analyzes the "theoretical/kinetic Africanist assumption that dance music-music which can provoke and sustain dance-carries performative qualities like those of language" (emphasis mine). He also generated the concept of "corporeal orature" to describe the alignment of movement with speech and state the ability of Black social dance to incite action. ${ }^{34}$ In my conception, the polarity of the performing body and the language that subtends it does not matter when the audience viscerally absorbs them because both bleed into each other. Performances and their various dimensions-songs, dances, and social actions-are in themselves a language that transcends linguistic borders. Performances can catalyze social changes because they are accessible as a visual-rhetoric force rather than linguistic or language-like forms. Theatre scholar, Rebecca Kowal's study of dance in the postwar USA has shown that we cannot only do things with words-following Austin's concept of performatives—but can also do things with dance performances. ${ }^{35}$

The creative appropriation of the language of African American resistance culture by nonmetropolitan Blacks (and other ethnic minorities) for their self-narrations is premised on what scholar of visual culture and Black history, Nicole Fleetwood, describes as their iconicity or the ways in which singular images or signs come to represent a whole host of historical occurrences and processes. ${ }^{36}$ The ability of iconic practices to travel on the interstate routes of American-dominated media, and arrive at local cultures to translate local narratives to even a local audience, shows how much world citizens are already situated at the interface of global and local cultures. As Osumare stated, global hip hop rode on the combined force of "the collision and collusion between two powerful globally pervasive forces; transnational media and capital and African American popular culture that remains steeped in Africanist expressive modes." ${ }^{\prime 37}$ In the moments of these linkages and dispersals of Black performance culture, and its subsequent conjoining with local inventiveness and artistic imperatives, even those who are not racially Black enrobe themselves in transcendental Blackness to ride the world on the political and aesthetic paths cleared by the worldwide reach of Black/American culture. ${ }^{38}$

The global travel of Black performance popular culture acts through the ubiquitous American media, and its evolution of a transculturally discernable lingua franca of socio-political critique makes Black American popular performance a node that interconnects different sites and locales of social confrontations. Thus, whether we say, Nigerian Lives Matter in Nigeria or on the streets of the UK, our reference connects to the history of anti-Blackness and anti- anti-Blackness in the US as a jump-off point for essentially saying Black lives do matter. When initiatives of resistance outside the USA appropriate the intangible structures of culture, values, and the activist ethic afforded by Black American performances, they create a translocal community of resistance across spaces. ${ }^{39}$ The re-narration of local oppressive circumstances engendered through the global echo effect of BLM

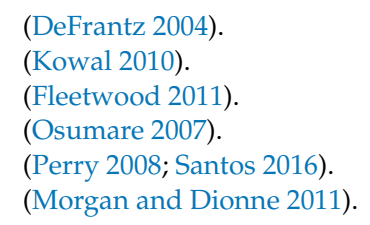


and This is America facilitate an international communal humanist ethos that sees white supremacy as a global ruling ideology and a common enemy. Their borrowing of graphic and catchy language that highlights their issues in local forms might not acknowledge American provenance, but it still demonstrates how performance kindles an ethical stance in us across space and time.

As Shana Redmond argues in Anthem: Social Movements and the Sound of Solidarity in the African Diaspora, what makes the Black songs that were deployed towards political resistance in the 20th century compelling was not just the sheer force of its artistry or the charisma of the performers. Rather, it was the inherent capability of those performances to formulate an audience of both the listeners and the political public that shared a sociopolitical stance. ${ }^{40}$ The political anthems were not just songs, but performative acts that generated a collective spirit of humanism in those who gathered to sing them. Participating in the performances required people to subscribe to a belief that in turn formulated the spirit of the assembly, that is, the faith that their desires can be achieved through the power of our collective human will. ${ }^{41}$ Similarly, the interchange of lexical subjectivity, such as Nigerian Lives Matter, that links different significations of aesthetic practices' negotiations for social change in different locales shows the potential of the decussation of language and performance to form an audience in multiple spaces and for those multifarious political acts to add up into a tessellated pattern of globalized resistance culture. From their different corners of the globe, and at ongoing periods of history, local actors are stimulated to test the tensile strengths of the repressive structures that shape their lives using the socio-political language that performance can enunciate. As both This is America and This is Nigeria show, when performances translate one other's situations, they form a web of political critique against oppressive social conditions even when the historical and social processes that hazard Black lives in both contexts differ.

\section{Conclusions: Black Lives Matter, Nigerian Lives Matter, Black Performances Matter}

To capture the worldwide links, complex processes, performative acts, and social connections that webs Black identity in the 21st century, scholar of theatre/dance, Nadine George-Graves provides us with an apt term, "spidering." ${ }^{22}$ Borrowing from Ghanaian folktale traditions where Anansi, the trickster figure, is frequently depicted as a spider, she uses the term to chart the Black diasporic cosmopolitan path where identity is allowed to be nuanced, complex, and its accretion through multiversal layering acknowledged. Indeed, "spidering" reminds us that the nodes that connect us do not emerge from a singular or unique location, but rather the formation of Black identity and the concomitant cultural issues they tackle are dispersed and diverse. "Spidering," to me, is also an evocative term that not only agglomerates the global dispersing and continuous expansion of Black identities but also captures the lightness of the connections that people make when they forge these subaltern cosmopolitanisms. However, these formations are neither permanent nor sustained but in the moment while they last, they spark the social imagination and create a mode of speaking about oneself and one's history within a symbolic ensemble that has the potential to impinge on the system of intersubjective relations between people as they narrate their histories within global paradigms. These are all made possible by Black performances because they are created based on the images of Black bodies depicted in different social situations. These images evoke an instinctive familiarity that speaks to people who also bear not just Black skin, but Black history, and that is why Black performances matter.

However, if these performances that take off from each other in different parts of the world have not yet risen to the point of rupture and propelled the drastic changes that are nostalgically conjured when we speak of different eras of Black internationalism, particularly the golden age of the 1960s,

\footnotetext{
40 (Redmond 2013).

41 (Redmond 2013, pp. 1-3).

42 (George-Graves 2014).
} 
it is partly because efforts are currently being slanted towards raising awareness for immediate local problems rather than a larger and collective angst. For now, it might be too early to conclude how these contemporary connections might turn out. My conclusion, however, is that the global Black formations of these times will continue to be fashioned as aesthetic practices but directed towards tackling political issues. The aesthetic will be the crucible for the forging of an ideologically-based nationalism that challenges the discounting of Black lives everywhere. At the core of the issues of race, racism, and white supremacy is the differentials of life and what they are worth based on the color of the skin that embodies them. It is instructive that the anti-racism speak of these performances aims straight at the heart of the matter: life, and particularly that of Black people.

The contemporary Black social movements that aim to topple down this pernicious ideology have struck on the language, both spoken and enacted, that challenges global white supremacy through an ethical summation of what is at stake: our lives matter. The dispersed nature of this movement, on the one hand, means that its proponents cannot build the critical mass necessary to galvanize collective energy to push back against factors that imperil Black lives everywhere. On the other hand, these discrete assemblies also mean that the house that racism built is being tested in many places and will eventually weaken through the political activism to which music and other aesthetic practices are oriented. The language of Black dignity and liberation will continue to provoke images and consciousness that will shape the ideology which the political agenda needs to thrive. For now, the seismic waves that are being generated are induced by the larger consciousness that our lives, as citizens of any country matter, and it should matter in spite of the larger ideological powers that detract from them based on the notion of color.

In conclusion, I also want to add that the waves of global Black migration will also critically contribute to the dynamics of these Black social movements. For instance, just as I was completing this essay, news came in that a Nigerian-American poet, Chinedu Okobi, had been tasered to death in Millbrae, California. The details of his death are still foggy and currently being investigated by the police at the time of writing this essay, but the news of his tragic death shook everyone who knew him within the Nigerian community. One of his close friends said on Facebook, "Until now, I have supported the Black Lives Matter movement on a low-key, but this one cuts so close to home. We Nigerians, regardless of where we live, now ought to join Black Americans to say, "Black Lives Matter." With that mindset that acknowledges that despite the artificiality of national borders and the ways they separate us, color still unites Black people across locations, there might be a hastening of consciousness of global Black identity and anti-Blackness.

While the constitution of the Black identity in the 21st century will still be fraught with historical and cultural complexities, the idea of a global Black still goes back to George-Graves' notion of "spidering." That is, the composition of Black identity in an increasingly shrinking world of cross-migrations and cosmopolitanism means that neither Nigerian Lives Matter nor This is Nigeria are mere subsets of Black Lives Matter or This is America. Instead, the project those performances fulfills is the encapsulation of a historical problem of anti-Blackness within smaller packages that not only bring them closer to home, but also translate back to the larger world with a lingua franca everyone understands. Each person that encounters violence, whether in an American racist or postcolonial African context, serves as a visceral reminder that one way or the other, our fates as Black subjects are interlinked not only by a history that is past but also an ongoing one as well. Because we are affectively touched by others' situations, our bodies are stimulated to respond to the voice of performance with embodied actions of our own.

When we need to make sense of local situations, we borrow inspirations from the spectacular kinetic performances of one culture and re-narrate it to explain our circumstances because artistic expressions are a language that affectively touches our humanity. This is Nigeria narrated the Nigerian condition using the performance frame of This is America, and also relied on the ground clearing work the latter had done to enhance the chronicles. Though the anti-Black violence in the USA is almost seamlessly transposed into the Nigerian context (or vice versa), the historical trajectories and sociological issues that imperil Black lives in the USA and Nigeria wildly differ. That is why the 
meditations on the cultural transactions embedded in both songs go beyond the mimesis of the lyrics, dance, and even the socio-political critique of This is Nigeria. The synchronism of the politics of both videos reflect how the vast frame of reference the USA gifted the cultures it has dominated over the years through its global media distribution, creative enterprise, and concomitant "soft power" that emerged to the USA's benefit, have generated a hip hop consciousness among the millennial generation and which continues to invite resistance against social conditions. The sense of identifying with Blackness through artistic cultural practices, harnessed and pressed into the service of political agency in other local contexts, fashions a visual-performative vernacular that also challenges the global inequity perpetrated by American cultural hegemony. ${ }^{43}$ The suffusion of disparate Black performances into other cultures has led non-Americans to find Black American performances and resistance practices approximate to translate and spell out their local politics of oppression, resistance, and protest within the concepts of anti-Blackness and anti- anti-Blackness whether they are deemed racially Black or not.

Funding: This research received no external funding.

Conflicts of Interest: The author declares no conflicts of interest.

\section{References}

Alim, Samy H., Awad Ibrahim, and Alastair Pennycook, eds. 2008. Global Linguistic Flows: Hip-Hop Cultures, Youth Identities, and the Politics of Language. New York and London: Routledge.

Austin, John L. 1962. How to do Things with Words. Oxford: Oxford University Press.

Azaransky, Sarah. 2017. This Worldwide Struggle: Religion and the International Roots of the Civil Rights Movement. Oxford: Oxford University Press.

Berger, Harris M., and Michael Thomas Carroll, eds. 2003. Global Pop, Local Language. Jackson: Univ. Press of Mississippi.

Blain, Keisha N. 2018. Set the World on Fire: Black Nationalist Women and the Global Struggle for Freedom. Philadelphia: University of Pennsylvania Press.

Botchway, De-Valera N. Y. M. 2014. Fela "The Black President" as Grist to the Mill of the Black Power Movement in Africa. Black Diaspora Review 4: 3-35.

Butler, Judith. 2015. Notes Toward a Performative Theory of Assembly. Massachusetts: Harvard University Press, p. 10.

Chiluwa, Innocent. 2015. 'Occupy Nigeria 2012': A Critical Analysis of Facebook Posts in the Fuel Subsidy Removal Protests 'Occupy Nigeria 2012': Un análisis crítico de las publicaciones en Facebook tras las protestas por la retirada de ayudas al combustible. Clina 1: 47-69.

Clare, Rod. 2016. Black Lives Matter: The Black Lives Matter Movement in The National Museum of African American History and Culture. Transfers 6: 122-25. [CrossRef]

Clark, Msia Kibona. 2018. Hip-Hop in Africa: Prophets of the City and Dustyfoot Philosophers. Athens: Ohio University Press.

Clarke, John Henrik. 2017. Pan-Africanism: A Brief History of an Idea in the African World. Présence Africaine 1: 26-56. First published 1988. [CrossRef]

Condry, Ian. 2006. Hip-Hop Japan: Rap and the Paths of Cultural Globalization. Durham: Duke University Press.

Cronin, Michael. 2013. Translation and Globalization. London and New York: Routledge.

Davary, Bahar. 2007. \# Black Lives Matter. Ethnic Studies Review 37: 11-14.

DeFrantz, Thomas F. 2004. The Black Beat Made Visible: Hip-hop Dance and Body Power. In Of the Presence of the Body: Essays on Dance and Performance Theory. Middletown: Wesleyan University Press, vol. 67, p. 69.

Diamond, Elin. 2003. Unmaking Mimesis: Essays on Feminism and Theatre. London and New York: Routledge.

Dolan, Timothy J. 2014. "Iraq Is the New Black": Performing Arabness in Arab American Hip-Hop. Bloomington: Indiana University.

Edwards, Sue Bradford. 2016. Black Lives Matter. Minneapolis: ABDO Publishing.

43 (Garofalo 1993; Morgan and Dionne 2011; Straubhaar 1991). 
Egbunike, Nwachukwu, and Anthony Olorunnisola. 2015. Social media and the\# Occupy Nigeria Protests: Igniting or damping a Harmattan Storm? Journal of African Media Studies 7: 141-64.

Feldstein, Ruth. 2012. The World Was on Fire: Black Women Entertainers and Transnational Activism in the 1950s. Organization of American Historians Magazine of History 26: 25-29. [CrossRef]

Fleetwood, Nicole R. 2011. Troubling Vision: Performance, Visuality, and Blackness. Chicago: University of Chicago Press, vol. 2.

Fleming, Tyler. 2016. A Marriage of Inconvenience: Miriam Makeba's Relationship with Stokely Carmichael and Her Music Career in the United States. Safundi 17: 312-38. [CrossRef]

Gaines, Kevin K. 2012. American Africans in Ghana: Black Expatriates and the Civil Rights Era. Chapel Hill: UNC Press Books.

Garofalo, Reebee. 1993. Whose World, What Beat: The Transnational Music Industry, Identity, and Cultural Imperialism. The World of Music 35: 16-32.

George-Graves, Nadine. 2014. Diasporic Spidering: Constructing Contemporary Black Identities. In Black Performance Theory. Edited by Thomas F. DeFrantz and Anita Gonzalez. Durham: Duke University Press, pp. 19-32.

Grant, Nicholas. 2017. Winning Our Freedoms Together: African Americans and Apartheid, 1945-1960. Chapel Hill: UNC Press Books.

Greenberg, Ela. 2009. 'The King of the Streets': Hip-hop and the Reclaiming of Masculinity in Jerusalem's Shu'afat Refugee Camp. Middle East Journal of Culture and Communication 2: 231-50. [CrossRef]

Hari, Solomon Ibrahim. 2014. The evolution of social protest in Nigeria: The role of social media in the “\# OccupyNigeria" protest. International Journal of Humanities and Social Science Invention 3: 33-39.

Hartman, Saidiya. 2007. Lose Your Mother: A Journey Along the Atlantic Slave Route. New York: Farrar, Straus and Giroux.

Ibrahim, Bisallah Hashim. 2013. Nigerians usage of facebook during 2012 Occupy Nigeria protests: Between networked and real public spheres. Science Journal of Researcher 5: 55-64.

James, Cyril Lionel Robert. 2012. A History of Pan-African Revolt. Oakland: PM Press.

Jegede, Joseph. 2018. Nigerian Lives Matter. July 10. Available online: https://elombah.com/nigerian-lives-matterjegede-joseph/ (accessed on 17 September 2018).

Johnson, Patrick E. 2006. Black Performance Studies: Genealogies, Politics, Futures. In The Sage Handbook of Performance Studies. Edited by Judith A. Hamera and Soyini Madison. California: Sage, pp. 446-63.

Kelley, Robin D. G. 1999. “But a local phase of a world problem": Black History's Global Vision, 1883-1950. The Journal of American History 86: 1045-77. [CrossRef]

Kelley, Robin, Dipannita Basu, and Sidney J. Lemelle. 2006. The Vinyl Ain't Final: Hip-hop and the Globalization of Black Popular Culture. London: Pluto Press.

Kowal, Rebekah J. 2010. How to Do Things with Dance: Performing Change in Postwar America. Connecticut: Wesleyan University Press.

Maultsby, Portia K. 1983. Soul Music: Its Sociological and Political Significance in American Popular Culture. The Journal of Popular Culture 17: 51-60. [CrossRef]

Mbembé, Achille. 2004. Aesthetics of Superfluity. Public Culture 16: 376. [CrossRef]

Meriwether, James Hunter. 2002. Proudly We Can Be Africans: Black Americans and Africa, 1935-1961. Chapel Hill: Univ. of North Carolina Press.

Monson, Ingrid. 2007. Freedom Sounds: Civil Rights Call out to Jazz and Africa. Oxford: Oxford University Press.

Morgan, Marcyliena. 2016. 'The World is Yours': The Globalization of Hip-hop Language. Social Identities 22: 133-49. [CrossRef]

Morgan, Marcyliena, and Bennett Dionne. 2011. Hip-hop \& the Global Imprint of a Black Cultural Form. Daedalus 140: 176-96.

Mose, Caroline. 2013. Swag' and 'cred': Representing Hip-hop in the African City. Journal of Pan African Studies 6: 106-32.

Olaniyan, Tejumola. 2004. Arrest The Music!: Fela And His Rebel Art and Politics. Bloomington: Indiana University Press.

Osumare, Halifu. 2001. Beat Streets in the Global Hood: Connective Marginalities of the Hip-hop Globe. Journal of American \& Comparative Cultures 24: 171-81. 
Osumare, Halifu. 2007. The Africanist Aesthetic in Global Hip-Hop: Power Moves. New York: Palgrave Macmillan, pp. 2-3.

Pennycook, Alastair. 2003. Global Englishes, Rip Slyme, and Performativity. Journal of Sociolinguistics 7: 513-33. [CrossRef]

Pennycook, Alastair. 2006. Global Englishes and Transcultural Flows. New York and London: Routledge.

Pennycook, Alastair. 2007. Language, Localization, and the Real: Hip-hop and the Global Spread of Authenticity. Journal of Language, Identity, and Education 6: 101-15. [CrossRef]

Perry, Marc D. 2008. Global Black Self-Fashionings: Hip-hop as Diasporic Space. Identities: Global Studies in Culture and Power 15: 635-64. [CrossRef]

Redmond, Shana L. 2013. Anthem: Social Movements and the Sound of Solidarity in the African Diaspora. New York: NYU Press, pp. 1-3.

Richardson, Elaine, and Gwendolyn Pough. 2016. Hiphop literacies and the globalization of Black popular culture. Social Identities 22: 129-32. [CrossRef]

Santos, Jaqueline Lima. 2016. Hip-hop and the Reconfiguration of Blackness in Sao Paulo: The Influence of African American Political and Musical Movements in the Twentieth Century. Social Identities 22: 160-77. [CrossRef]

Saucier, Paul Khalil, ed. 2011. Native Tongues: An African Hip-hop Reader. New York: Africa World Press.

Shonekan, Stephanie. 2018. Black Mizzou: Music and Stories One Year Later. In Black Lives Matter and Music: Protest, Intervention, Reflection. Edited by Portia K. Maultsby. Bloomington: Indiana University Press.

Sizemore-Barber, April. 2012. The Voice of (Which?) Africa: Miriam Makeba in America. Safundi 13: $251-76$. [CrossRef]

Slate, Nico. 2012. Colored Cosmopolitanism: The Shared Struggle for Freedom in the United States and India. Cambridge: Harvard University Press.

Straubhaar, Joseph D. 1991. Beyond Media Imperialism: Assymetrical Interdependence and Cultural Proximity. Critical Studies in Media Communication 8: 39-59. [CrossRef]

Strong, Krystal. 2018. Do African Lives Matter to Black Lives Matter? Youth Uprisings and the Borders of Solidarity. Urban Education 53: 265-85. [CrossRef]

Terkourafi, Marina, ed. 2010. The Languages of Global Hip-Hop. New York: Continuum.

Thomas, Dexter L. 2016. Niggers and Japs: The Formula behind Japanese Hip-hop's racism. Social Identities 22: 210-25. [CrossRef]

Thompson, Vincent Bakpetu, and Basil Davidson. 1969. Africa and Unity: The Evolution of Pan-Africanism. London: Longman.

Weiss, Brad. 2009. Street Dreams and Hip-Hop Barbershops: Global Fantasy in Urban Tanzania. Bloomington: Indiana Univ. Press.

West, Michael Oliver, William G. Martin, and Fanon Che Wilkins, eds. 2009. From Toussaint to Tupac: The Black International Since the Age of Revolution. Chapel Hill: Univ. of North Carolina Press, vol. 3.

Wilson, Stephanie. “Nigerian Lives Matter.” Dazed Digital. Available online: http://www.dazeddigital.com/ artsandculture/gallery/19178/11/nigerian-lives-matter (accessed on 18 September 2018).

(C) 2019 by the author. Licensee MDPI, Basel, Switzerland. This article is an open access article distributed under the terms and conditions of the Creative Commons Attribution (CC BY) license (http://creativecommons.org/licenses/by/4.0/). 